Botany: Hillhouse, Trinity, and Hoffmeister, Caius (distinguished); and three for Zoology, Anatomy, and Physiology: Caldwell, Caius; Pigeon, Christ's ; and Shaw, Sidney.

Mr. J. A. Fleming, B.A., of St. John's, has been appointed to the new post of Demonstrator of Mechanism and Applied Mechanics; Mr. Flening is a distinguished graduate of London University, as well as having attained distinction in Physics, with first class honours in the Natural Science Tripos of this year.

Mr. J. Y. Lister, B.A, of St. John's College, has been appointed Demonstrator of Comparative Anatomy, in place of Mr. A. C. Haddon, who has been appointed to the Professor ship of Zoology and Comparative Anatomy in the Royal College of Science, Dublin, vacated by Prof. Bridge.

Mr. A. H. Cooke, B.A., Fellow of King's College, has been appointed Curator of the Zoological Museum.

\section{SCIENTIFIC SERIALS}

Annalen der Physik und Chemie, No. II.-Magnetic researches, by F. Auerbach.-New researches on magnetism, by C. Baur.-On so-called polar induction, by E. Riecke.-Determination of the absolute velocity of current electricity from Hall's phenomenon, by A. v. Ettingshausen.-Method of calibration of a wire for galvanic measurements, by W. Giese. -Action of gases and vapours on the optical properties of re. flecting surfaces, by P. Glan.-On a new interference-photometer, by Fr. Fuchs.--Influence of the density of gases on their conduction of heat, by A. Winkelmann.-Currents of liquids resulting from unequal temperature within them, by $\mathrm{A}$. Oberbeck. - Theory of the interference-phenomenon presented by dichroïtic crystal-plates cut at right angles to the axis, by E. Ketteler.On the polarisation of diffracted light, by M. Kethy.-On changes produced in the spark and brush phenomena by coverings of the electrodes, by W. Holtz.-On atmospheric refraction of sound rays, by A. Kneser.-Double-acting mercury-pump without cock, by $F$. Neesen.-Alteration of Riidorff's absorptionhydrometer, by the same - Reply to a note by O. E. Meyer, by L. Boltzmann.-Remarlss on U. Duihring's paper on the law of corresponding boiling temperatures, by A. Winkelmann.

\section{SOCIETIES AND ACADEMIES LONDON}

Zoological Society, December 14.--Prof. W. H. Fowler, LL.D., F.R.S., president, in the chair.-Mr. Sclater exhibited and made remarks on a skin of a brown female of Pauxis galeata, formerly living in the aviary of the late Mr. G. Dawson Rowley, F.Z.S.-Dr. A. Giinther, F.R.S., exhibited and made remarks on a skin of a new species of Rhynchocyon from Eastern Africa, discovered by Dr. Kirk. - Prof. T. H. Huxley, F.R.S., read a paper on the application of the laws of evolution to the arrangement of the Vertebrata, and more particularly of the Mammalia. -Lieut. Col. H. H. Godwin-Austen, F.R.S., read a paper on the anatomy of Ferussacia gronoviana, Risso, from Mentone, pointing out its general relationship with Lovea tornatellina, Lowe, of Madeira, and with Ferussacia follicula, Gronov., from Algiers.-Mr. Arthur G. Butler read a paper on a second collection of Lepidoptera made in Formosa by Mr. H. E. Hobson. Thirty-three new species were found in this collection.- Mr. Oldfield Thomas, F.Z.S., read a paper containing the description of a new species of Reithrodor, obtained in Venezuela by the late Mr. D. Dyson, which was described as Reithrodon alstoni.-Dr. A. Günther read a paper containing notes on some rare reptiles and batrachians now or lately living in the Society's Gardens.

Physical Society, December II.-Prof. W. G. Adams in the chair.-New Members : Mr. W. R. Brown, Mr. T. Mightson, C.E.-Lieut. L. Darwin read a paper on the rate of loss of light from phosphorescent substances. His experiments were made at Chatham on Balmain's luminous paint, by comparing the intensity of the phosphorescent light with the light of a sun-burner; the luminous surface being kept cool by placing ice and water near, as a slight increase of temperature in the surface considerably increases the quantity of light given off in a certain space of time. The supply of light was communicated to the paint from a mirror reflecting sunlight. A table and a curve exhibited to the meeting showed the rate of loss found by Lieut. Darwin. It is independent of the original intensity of of the illumination. According to the curve the light diminishes very nearly in proportion to the square of the intensity of the light. In a report on the use of Balmain's paint in mines, it had been stated that the phosphorescence became brighter a few minutes after exposure in the dark; but the curve showed this to be an error, due probably to the fact that the eye become. more sensitive to light after being a few minutes in the dark. Mr. Pearsall emphasised the advantages of such a light in fiery mines. Prof. Guthrie inquired if the phosphorescent power grew weaker by time, and Lieut. Darwin instanced a specimen eighty years old to the contrary; but Dr. W. Crookes stated that these luminous substances give off sulphuretted hydrogen in damp air and deteriorate. If sealed in a vacuum they would not. Dr. Crookes remarked that in Balmain's patent it was stated that the phosphorescence died out sooner when exposed to a strong light for a short time than to a weak light for a longer time; but Lieut. Darwin thought this was explained by the slow decrease in the lower part of the curve when the phosphorescence became faint. Mr. R. J. Lecky mentioned that Evelyn in his Diary ( 1650 ) describes a phosphorescent powder as "bottling up" sunlight. Dr, Coffin inquired if short exposure to strong light was equivalent to long exposure to feeble light. Lieut. Darwin thought not.-Dr. C. R. Alder Wright read a full paper on the determination of chemical affinity in terms of electromotive force. $\mathrm{He}$ considered first the value of the B.A. unit of resistance, which from different experimenters might be taken as really I 005 earth quadrants per second, or not more than half per cent. out. Clark's element when carefully prepared was practically correct at $\mathrm{I} 457$ volts, and it kept constant for three or four months after being made, but deteriorated thenceforth some 3 per cent. in about two years. The deterioration was assisted by air, which could not be well exchnded by the paraffin cork, as it cracked. If sealed in a Sprengel vacuum the element lasted better. Joule's mechanical equivalent of heat $(J)$ he estimated at $42 \times 10^{6}$, or not over 1 per cent. greater than Joule's water value. The chief result of Dr. Wright's researches was the conclusion that the action of a current in electrolysis is to decompose the electrolyte into " nascent" products which evolve heat in changing into ordinary products of electrolysis. These nascent products may be the ultimate atoms composing the molecules of the ordinary products, and the heat is given out in these atoms coming together to produce molecules, say of oxygen and hydrogen in the case of water. A number of deductions from this theorem are verified by experiment. One of these is that no gas battery can give a higher E.M.F. than $\mathbf{1}^{\circ} 5$ volts. A result, not before published, is that the E.M.F. of a Daniell cell is a function of the current and is a maximum when the current is indefinitely small. The variation may amount to ro degrees. Therefore all methods of determining resistance by means of two currents of different strength are inaccurate. Dr. Wright's experiments also verified Faraday's law that conduction in an electrolyte is always accom. panied by electrolysis. Prof. Adams inquired if Dr. Wright had seen the letter of Prof. Rowland's assistant to the effect that Dr. Wright's former estimate of the ohm was on the wrong side of unity. He had been too busy to see it. Prof. Foster thought that the variation of E.M.F. in a cell with the current was to be expected, and was probably due to the slowness of diffusion. Dr. Wright thought diffusion would account for it. Dr. Lodge said that there was no way of measuring the resistance of a cell except by employing two currents of different strength, and therefore it was necessary to know the law of variation of E.M.F. with current strength. Dr. Wright stated that he had found two methods of proceeding with currents of the same strength. With regard to the deduction of Dr. Wright that no current passes without producing electrolysis, Mr. Walenn inquired if the ordinary law of solution held when there was no evolution of hydrogen, and was answered in the affirmative.-Prof. Guthrie cited the experiments of Mr. C. V. Boys and himself on the conductivity of liquids as an instance of a current passing without electrolysis, or if there was decomposition it was followed by instant recomposition. Dr. Wright thought there must be electrolysis in Dr. Guthrie's experiments (which were conducted by rotating a glass vessel filled with the liquid between the poles of a magnet, after Arago's experiment), because some two parts of the rotating vessel would be at different potentials, and a current would be set up in the liquid.-The Society then adjourned till after Christmas.

\section{PARIS}

Academy of Sciences, December I3.-M. Edm. Becquerel in the chair.-The following papers were read:-Solid and 
liquid products which continued issuing in April, 1880, from a crater of Dominica (English Antilles), by M. Daubrée. The lake of boiling water which filled the crater in January had shrunk to a boiling spring, the dark liquid from which joined a river. The weight of solid matter is nearly half the liquid, and mainly consists of silica and alumina; there is also iron oxide, with carbonate of lime, \&c. Chloride of potassium abounds in the water.-Order of appearance of the spikelets in the ear of Lolium, by M. Trécul.-On the orbit described by a material point which is attracted by a spheroid, by M. Gyldén. -M. Abria was elected Correspondent in Physics in place of M. Lisssajous. -A pplication of the theory of germs to parasitic champignons on plants, and especially to diseases of the vine, by M. Cornu. In some cases the diseased leaves may be variously utilised, after such treatment as will prevent the spores being disseminated when their time of vegetation comes. Other kinds of parasites do not alluw of the leaves being used as food for cattle, compost, or litter. Their dormant spores are not killed by digestion or putrefaction of tissues; after prolonged burial they may produce new germs. The débris in that case should be burnt. Oidium and anthracnose exemplify the former; peronospora the latter.-On the discovery of the winter egg in the Eastern Pyrenees, by M. Campana. He found three in the end of September.-On a process of preparation of sulphide of carbon in the solid state for treatment of phylloxerised vines, by $M$. Lafaurie. He solidifies the sulphide by making an emulsion of it with a solution of algæ (Japanese moss does very well). The proportion of sulphide may be varied up to 80 per cent. It evaporates very slowly, so that vapours can be thus maintained a long time about the roots. - Swift's comet (e I880), by MM. Schulhof and Bossert.-Influence of the slope of refringence on astronomical refraction, by $M$. Glasenapp. By this term he denotes the effect of atmospheric layers of equal density not being generally distributed in concentric surfaces on the earth's surface (as they are supposed to be in all theories of astronomical refraction). He proposes to investigate the influence of this phenomenon and its law of variation; to find whether it have an annual period, and if so, of what nature; to study the influence of this on the annual parallax of fixed stars and their aberration; also to study lateral refraction.-On the contact of conics and surfaces, by $M$. Darboux.-On a class of linear differential equations, by $M$. Appell.- On the integration of equations with partial derivatives of the first order, by $M$. Collet. - On linear differential equations of the second order, by M. Mittag-Leffler. -Reclamation of priority on the subject of the law of corresponding boiling temperatures, by $M$. Diuhring. - On radiophony (second note), by M. Mercadier. The sounds may be got from oxyhydrogen lamps and gas lamps without concen. trating lenses, if the lamps be brought very near the (glass) interrupting wheel, and the rays limited by a diaphragm with aperture. A copper disc $(0.002 \mathrm{~m}$. thick) was placed near the wheel, and heated on the side opposite to that of the wheel with an oxyhydrogen blowpipe. Sounds were heard when the disk still remained invisible in the dark (though louder when the disk was raised to a dark or bright red).-On new and economic methods of producing intermittent luminous signals, by $M$. Mercadier. Instead of using a diaphragm with a constant source of light, he varies the source; e.g. by introducing oxygen suddenly into a low flame. This is done by pressing a key, and so releasing from pressure a tube conveying the oxygen.-On the absorption-spectrum of ozone, by M. Chappuis. Eleven dark bands are observed in the visible spectrum, and several correspond with telluric bands of the solar spectrum.-Action of hydrochloric acid on metallic chlorides, by M. Ditte.-Action of hydrofluoric acid on bichromate of ammonia, by M. Varenne.On chlorised derivatives of strychnine, by MM. Richet and Bouchardat. They have isolated three such compounds, retain. ing in different degrees the chemical properties of strychnine. On the cause of spontaneous alteration of the raw sugar of cane, by M. Gayon. He gives reasons for thinking this process a true fermentation.-On the variations of luminous sensibility according to the extent of the retinal parts excited, by M. Charpentier. One region, seventeen to eighteen hundredths of a millimetre in diameter, and corresponding to the fovea centralis, requires a determinate quantity of light, independent of the extent of surface, to excite it. In other parts the minimum illumination is proportional to the surface.-Anatomic researches on Onchidium, Cuv. (Oncidiella celtica, Gray), by $M$. Joyeux Laffine. - Serpentines of Corsica; their age and origin, by $M$. Dieulafait. M. Hebert dissented from some of the results in this paper.

\section{VIENNA}

Imperial Academy of Sciences, December I6.-Herr v. Burg in the chair. - Table of the most important relations of astronomy and geography, by Herr Letoschek.-Further researches on identity of the comets I869 III. and I $880 e$, by Herr Zelbr and Dr. Hepperger.-On leucæmia, by Herr Ludwig.Fourth report of the Prehistoric Commission, containing (I) Szombathy on this year's prehistoric investigations and excavations at Kiritein and Mokrau in Moravia ; (2) Luschau on several old burial-places in Bosnia and Dalmatia; (3) Heger on skeleton graves of Tlonic, grave-mounds at Tschemin (Bohemia) and at Wässering in Lower Austria, and tumuli at Mars in Hungary.Theoretical researches on the displacements of the radiationpoints of dissolved meteor-streams, by Herr v. Riessl. - Application of hyposulphate of soda to separation of copper from cadmium, by Herr Vortmann.--Some experiments on an earth magnetic inductor, by Herr Stefan.

\section{BERLIN}

Geographical Society, December 4.-Dr. Nachtigal in the chair.-It was stated inter alia that Herr Flegel, who is busy in the Niger region, had gone from Lukodja to the King of Nupe or Nife, seeking letters of introduction to the rulers of the Haussa States, so as to make a safe journey up the Niger, especially on the stretch between Tawa and Sai. He had a friendly reception, and wrote in good hopes (October 10). From Sai he means to go to Sokoto, the chief town of the Haussa States, and there to get letters for the ruler of Adamaua. A large collection of ethnological objects of the Niger regicn is looked for in Berlin. - Rumours of the death of Herr Hildebrandt in Mada. gascar prove false. A letter from him dated Krabé in Bessileo (Central Madagascar), September 2, I880, states that he had made a journey, rich in results, from the West Coast to the Central Plateau; but his health broke down, when he was two hours' journey from the capital, to which however he was shortly brought by Herr Cousins and tended for a time in the Norwegian mission-house till able in July to visit the hot springs of Sirale (for health). He discovered in the moor at Siralé the skeleton of an extinct species of hippopotamus.-Dr. Kiepert gave details of Mr. Doughty's expeditions in Central Arabia, which have cleared up much of the physical geography of that region. -Dr. Holub spoke on the Maruthameich in sonthern interior Africa, north of the lower, and about the middle course of the Zambesi.

\section{CONTENTS}

PAGE

THE FOGS OF LONDON

WHAT IS CiVILISATION

OUR BOOK SYRIOPODS

Schmeltz and Krause's "Die Ethnographisch-Anthropologische Abtheilung des Museum Godeffroy in Hamburg. Ein Beitrag zur

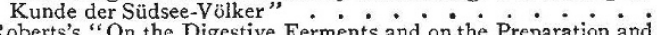

Roberts's "On the Digestive Ferments and on the Preparation and
Use of Artificially-Digested Food". . . . . .

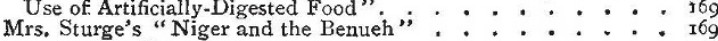
LETTERS TO THE EDITOR :-

Smokeless London.-W. Matrieu Williairs; E. R. F.

Climates of Vancouver Island and Boumemouth.-ALFRED $R$.

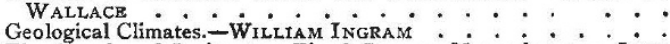

The Appulse of Jupiter to a Fixed Star on November 20.-Jon BIRMINGHAM

British Earthquakes.-Prof. J. P. O’Railry . . . : : . I7o

A General Theorem in Kinematics.-Gronge M. Minchin . . . 170

A Correction.-Prof. Franz Exner . . . . . . . . . . . 170

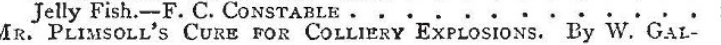
LOWAY

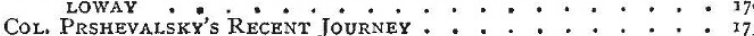

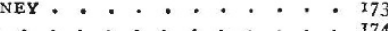

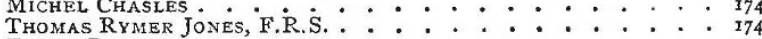

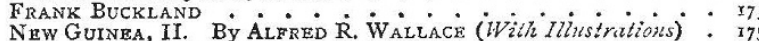

Physiology of PlanTS. By FRANCIS DARWIN . . . . . .

Notes . . . . . . . . . 18

OUR Astronomical Column:-

Swift's Comet

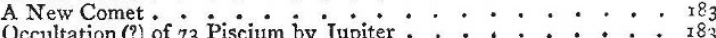

Metrorolocical Notes

GEOLOGICAI NOTES:-

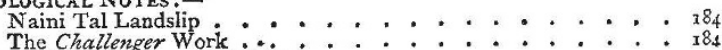

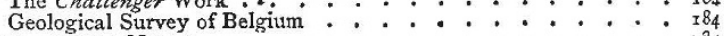

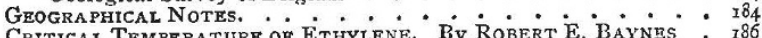

Critical Temperature of Ethylene. By Robert E. BAYNeS - 186 UNIVERSTTY AND EDUCATIONAL INTELLIGENCE •

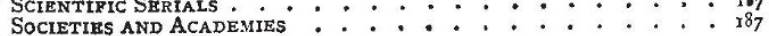

